\title{
Empirical Study of the Influence Factors of the Servitization Strategy Performance of High-tech Manufacturing Enterprises Based on Industry Classification Data
}

\author{
Li Wei ${ }^{1, a}$, Huijun Chen ${ }^{2, b}$
}

${ }^{1}$ School of Economic \& Management, Lanzhou University of Technology, Lanzhou 730050, China;

2 School of Economic \& Management, Lanzhou University of Technology, Lanzhou 730050, China.

avivian_0416@126.com, bchhj_happy@126.com

\begin{abstract}
There is a strong marginal substitution effect on service input to technology input for service strategy adopted by high-tech manufacturing enterprises during technological bottleneck period, and a new way to profit growth points. That's why many high-tech manufacturing enterprises choose it. However, service performance of high-tech manufacturing enterprises is affected by many factors. With "technological innovation capability and service that affect service performance being core variables" as research hypothesis, it takes enterprise size, asset-liability ratio as control variables to build linear regression model based on data 2012-2016 of high-tech enterprise in five major industries from WIND database. According to the empirical test, it concludes that there is a significantly positive correlation between "technological innovation ability", "service degree" and enterprise service performance.
\end{abstract}

Keywords: high-tech manufacturing enterprise; service-oriented performance; technological innovation ability; service-oriented degree; empirical test.

\section{Introduction}

As China's economy develops, it is traditional manufacturing industrial upgrading that matters a lot for government.(Tongjiadong,2017)[1].Scholars attracted by"Manufacturing enterprise servicing" and reach a consensus (Tang Zhifang, 2018) [2]. Service in high-tech manufacturing enterprises will have a higher marginal substitution effect with intensive knowledge and technology, technological staff,software production, fast replacement and high added value of products (Wang Yangdong, 2007) [3], so it's easier to improve efficiency of services both internal and external, ultimately contributing to overall performance.However, service strategy impacts in high-tech manufacturing enterprises is becoming increasing different. (Li Wenxiu, 2012) [4]. This paper argues that some specific factors must explain different service performance. The core variables that affect the service performance and appropriate way to achieve their expected service performance will be found in service strategic implementing of high-tech manufacturing enterprises.

\section{Literature Review}

\subsection{Literature Review on Factors Influencing Service-oriented Performance of High Technology Manufacturing Enterprises}

The concept of service-oriented manufacturing enterprises was first proposed by Vandermerwe \& Rada (1988) [5]. Contemporary, scholars such as Markusen (1989) [6], Wasserman (1994) [7], believe that new strategies must be adopted during technological bottleneck period, or it will be difficult to achieve sustainable growth. Eventually, the service strategy as an alternative became the main research objectives for scholars, such as Anderson (1995) [8], Miller (2002) [9]. For service performance evaluation, Kelly (2000) [10] thought that it needs to express its "quantification"by competitive performance, performance of market, sales, financial and cost while "service" should be fully considered.Cooper (2000) [11] proposed that it should be measured by three indicators: opportunity window, market impact and financial performance, while De Brentani (2001) [12] suggested that from financial indicators, internal indicators and customer indicators on the level of 
case and stage project. With correct evaluation system and indicators, key factors affecting the service performance of high-tech manufacturing enterprises will be found.

\subsection{The Enlightenment of the Literature Review to the Research Hypothesis in This Paper}

Now, it's the key point to learn how to allocate the limited service elements best to achieve its maximum efficiency from academic analysis. Accordingly, this paper argues that service performance will be affected by "quality" and "quantity", making these two factors more "variable or index" and "operable" in data acquisition. "Technological innovation capability "will be used to express the "quality" of the service elements invested, and the "enterprise service level" to "quantity". Therefore, this paper takes "technological innovation capability" and "service level" as the basic hypothesis for empirical study, and try to prove it.

\section{Model and Empirical Study}

\subsection{Model Building}

\subsubsection{Research Hypothesis}

As mentioned before, the utilization efficiency determined by "quality" and "quantity" of the service factors invested determines the service performance of high-tech manufacturing enterprises. Hence, this paper argues its ultimate impact. The key factors of transforming performance mainly come from "technological innovation ability" (service factor "quality") and "service level" (service factor "quantity")

Therefore, two hypotheses need to be tested empirically:

Hypothesis 1: There should be a significant positive correlation between "technological innovation capability" and "service performance" in high-tech manufacturing enterprises.

Hypothesis 2: There should be a significant positive correlation between "service degree" and "service performance" in high-tech manufacturing enterprises.

\subsubsection{Model Setting}

According to the hypothesis proposed previously, it's significantly positive correlation between "technological innovation capability (R\&D)","service degree (Serv)" and "service performance (ROE)". Still, there are some constraints on it. First, the relationship works only for high-tech manufacturing enterprises; second, operating conditions must be normal; finally, "high-tech manufacturing" attributes of enterprises can't be changed. In this, some control variables are needed, like enterprise size (Lnsize), asset-liability ratio (Debt), service degree and enterprise size interaction (Serv * Lnsize), service degree and asset-liability ratio interaction (Serv* Debt), so the final regression model expression is:

$\mathrm{ROE}=\mathrm{B} 0+\mathrm{B} 1 \mathrm{Serv}+\mathrm{B} 2 \mathrm{R} \& \mathrm{D}+\mathrm{B} 3 \mathrm{Debt}+\mathrm{B} 4 \mathrm{LnSize}+\mathrm{B} 5 \operatorname{Serv}^{*}$ LnSize+B6Serv*Debt $+\mu(1)$

among $\mathrm{Bn}(\mathrm{n}=0,1,2, \ldots \ldots, 6)$ is the corresponding coefficient of each variable, and the $\mu$ is the error.

\subsection{Data Acquisition and Variable Handling}

\subsubsection{Data Acquisition}

With high-tech manufacturing enterprises as objectives, it chooses the data of Listed Companies in high-tech manufacturing industry under the screening function of the WIND database, referring to high-tech and manufacturing industry from the "China High-tech Industry Statistics Yearbook". Sample enterprises were selected from five major industries: instrument manufacturing; vehicle manufacturing and other manufacturing; pharmaceutical manufacturing; chemical raw materials and chemicals manufacturing; computer communications and other transport equipment manufacturing. According to the National Economic Industry Classification Standard (GB/T4754-2011), companies without service business are eliminated firstly. However, the listed companies of ST and * ST are eliminated. In the time dimension, to improve the efficiency and ensure data continuity and integrity, 
data from 2012 to 2016 were selected, and eliminates the missing listed companies again. Eventually,1700 research samples are available.

\subsubsection{Variable Handling}

Before the empirical analysis, the explained variables, explanatory variables and control variables involved in the model need be defined and explained.

(1) Service-oriented performance (ROE): it's a vital index to quantify the effect of service-oriented performance, the financial performance created by unit service elements. Service-oriented performance $=$ the increment of financial performance / service elements input, in which enterprise financial performance can be directly expressed, such as the return on net assets, total return on assets, etc., But considering non-recurrent gains, losses and tax impact on the ultimate profitability, it argues that it's more scientific to choose ROE (Return on Net Assets) to express the financial performance. As service factor input increasing, the accuracy of "service performance" quantification might reduce, the speed of the input increment of service factors are relatively close, so that the enterprise "financial performance" can form a substitute expression for "service performance".

(2) Degree of service (Serv): its definition is mainly based on similar literature, taking service level of high-tech manufacturing enterprises expressed by the ratio of service business income to total income as its consensus. With data characteristics of WIND database, it believes that company's offbusiness income can express its service business income. Therefore, this paper quantifies service degree (Serv) by the ratio of its off-business income to total income.

(3) Technological Innovation Capability (R\&D): according to R\&D expenditure, it's proposed that R\&D expenditure representing companies' technological innovation capability, the relationship between them is developing similarly. Therefore, this paper takes the ratio of R\&D expenditure to business income as a quantitative indicator of technological innovation capability.

(4) Enterprise Scale (LnSize): enterprise size determines standardization of internal management and control, and allocation efficiency of the service elements invested by enterprise. Therefore, enterprise size should have a certain impact on service performance of high-tech manufacturing enterprises. This paper selects the natural logarithm of the company's main business income to express enterprise scale.

(5) Asset liability ratio (Debt): the ratio of total liabilities to total assets. It might affect high-tech manufacturing enterprises when carry out service-oriented business.

(6) Interaction between enterprise scale and service degree (LnSize*Serv):it is to explain that enterprise scale may affect service degree because of different internal management and control. Enterprise scale will form a certain moderating effect on its service degree, which is imposed by enterprise scale. The impact of operation degree may also have an impact on the companies' service performance.

(7) Interaction between asset-liability ratio and service degree (Debt*Serv): the impact of service degree imposed by asset-liability ratio may have an impact on service performance.

\subsection{Regression Analysis}

With variables above, data of five major industries from 2012 to 2016, the final analysis results are shown in Table 3-1: the last column is the variance expansion of each variable, its value is far less than 10, indicating no col-linearity between these variables. It's the basis of regression analysis; then, from the correlation analysis between the variables and the explained variables, the correlation between the technological innovation ability (R\&D), service degree and the explained variables is significant, while the correlation between the control variables and the interpreted variables is significant; then, regression analysis results show that the regression coefficients of technological innovation ability (R\&D) and service degree are significant, and there is a positive correlation between them. The $\mathrm{F}$ test shows that the regression equation is significant integrally, and the $\mathrm{T}$ value is also significant. So, there is a significant positive correlation between them. 
Table 1. Regression analysis results of five industries in five industris

\begin{tabular}{|c|c|c|c|c|c|c|c|c|}
\hline \multirow{2}{*}{\multicolumn{2}{|c|}{$\begin{array}{l}\text { Correlation coefficient between } \\
\text { ROE and variables }\end{array}$}} & \multirow{2}{*}{ Model } & \multicolumn{2}{|c|}{$\begin{array}{l}\text { Non-standardized } \\
\text { coefficient }\end{array}$} & $\begin{array}{l}\text { Standard } \\
\text { coefficient }\end{array}$ & \multirow{2}{*}{$\mathrm{t}$} & \multirow{2}{*}{ Sig. } & \multirow{2}{*}{ VIF } \\
\hline & & & B & $\begin{array}{l}\text { Standard } \\
\text { error }\end{array}$ & Trial Edition & & & \\
\hline ROE & 1 & constant & $10.232 *$ & .662 & & 15.455 & .000 & \\
\hline R\&D & $.216^{* *}$ & $\mathrm{R} \& \mathrm{D}$ & $.124 *$ & .047 & .065 & 2.612 & .009 & 1.278 \\
\hline Serv & $.351^{* *}$ & Serv & $.337 *$ & .082 & .199 & 4.122 & .000 & 1.270 \\
\hline LnSize & $-.228^{* *}$ & LnSize & $-.011^{*}$ & .003 & -.111 & -3.544 & .000 & 1.315 \\
\hline Debt & $.089^{* *}$ & Debt & .029 & .016 & .050 & 1.841 & .066 & 1.558 \\
\hline Serv*LnSize & $-.093^{* *}$ & Serv*LnSize & $-.004 *$ & .001 & -.110 & -3.407 & .001 & 1.175 \\
\hline Serv*Debt & $.358^{* *}$ & Serv*Debt & $.008 *$ & .002 & .176 & 3.717 & .000 & 1.674 \\
\hline F statistics & & & & 324 & & & .000 & \\
\hline Adjusted $\mathrm{R}^{2}$ & & & & & & & & \\
\hline
\end{tabular}

Note: The correlation coefficient **. was significantly correlated at the level of. 01 (bilateral), *. significantly correlated at 0.05 (bilateral). The significant level of regression results was 0.05 .

\subsection{Robustness Test}

Based on sample data, the correlation analysis and regression analysis are carried out. The relationship between technological innovation ability and service degree and service performance of high-tech manufacturing enterprises is tested empirically. To ensure the result robustness, and differences between different industries. In this paper, regression tests are conducted on sample data according to industry grouping.

Table 2. Group test of five industries: correlation analysis and collinearity analysis of explanatory

\begin{tabular}{|c|c|c|c|c|c|c|c|c|c|c|}
\hline \multirow[t]{2}{*}{ Variable } & \multicolumn{2}{|c|}{$\begin{array}{c}\text { Railways, ships, } \\
\text { aerospace } \\
\text { manufacturing and } \\
\text { other } \\
\text { manufacturing } \\
\text { industries. }\end{array}$} & \multicolumn{2}{|c|}{$\begin{array}{l}\text { Chemical raw } \\
\text { materials and } \\
\text { chemical products } \\
\text { manufacturing } \\
\text { industry }\end{array}$} & \multicolumn{2}{|c|}{$\begin{array}{c}\text { Computer } \\
\text { communications and } \\
\text { other transport } \\
\text { equipment } \\
\text { manufacturing } \\
\text { industry } \\
\end{array}$} & \multicolumn{2}{|c|}{$\begin{array}{l}\text { Pharmaceutical } \\
\text { manufacturing } \\
\text { industry }\end{array}$} & \multicolumn{2}{|c|}{$\begin{array}{l}\text { Instrument } \\
\text { manufacturing } \\
\text { industry }\end{array}$} \\
\hline & $\begin{array}{c}\text { Correlation } \\
\text { coefficient } \\
\text { between } \\
\text { ROE and } \\
\text { variables }\end{array}$ & VIF & $\begin{array}{l}\text { Correlation } \\
\text { coefficient } \\
\text { between } \\
\text { ROE and } \\
\text { variables }\end{array}$ & VIF & $\begin{array}{c}\text { Correlation } \\
\text { coefficient } \\
\text { between ROE } \\
\text { and variables }\end{array}$ & VIF & $\begin{array}{l}\text { Correlation } \\
\text { coefficient } \\
\text { between } \\
\text { ROE and } \\
\text { variables }\end{array}$ & VIF & $\begin{array}{l}\text { Correlation } \\
\text { coefficient } \\
\text { between } \\
\text { ROE and } \\
\text { variables }\end{array}$ & VIF \\
\hline ROE & 1 & & 1 & & 1 & & 1 & & 1 & \\
\hline R\&D & $.671^{* *}$ & 1.082 & $.309^{* *}$ & 1.204 & $.347^{* *}$ & 1.384 & $.757^{* *}$ & 1.177 & $.594^{* * *}$ & 1.324 \\
\hline Serv & $.816^{* *}$ & 1.059 & $.501^{* *}$ & 1.052 & $.475^{* *}$ & 1.295 & $.699^{* * *}$ & 1.243 & $.751^{* *}$ & 1.565 \\
\hline LnSize & $-.803^{\text {** }}$ & 1.367 & $-.285^{* *}$ & 1.425 & $-.331^{* *}$ & 1.765 & $-.428^{* *}$ & 1.602 & $-.719^{* *}$ & 1.593 \\
\hline Debt & $-.328^{* *}$ & 1.231 & $-.192^{* *}$ & 1.320 & $.121^{* *}$ & 1.586 & .024 & 1.072 & $.313^{* *}$ & 1.163 \\
\hline Serv*LnSize & $-.416^{* *}$ & 1.796 & -.040 & 1.726 & .027 & 1.420 & $-.106^{*}$ & 1.809 & -.122 & 1.738 \\
\hline Serv*Debt & .086 & 1.845 & $.150^{*}$ & 1.229 & $.491^{* *}$ & 1.454 & $.613^{* *}$ & 1.554 & $.728^{* *}$ & 1.363 \\
\hline
\end{tabular}

Table 2 shows significant positive correlation between explained variable and explanatory variable, there is a significant difference between control variable and explained variable. The empirical study results are consistent, indicating that the results of correlation analysis are robust and effective.

Table 3 shows that $F$ regression is adopted in each regression, representing significant equation. Comparing with Table 1, technological innovation capability of vehicle and other manufacturing industries is not significant (the data of 2012 R\&D investment is missing, and take average data of other years.). The regression coefficients of technological innovation ability of other industries are basically consistent with regression results, significantly positive; Regression coefficients of service degree of all industries are consistent with regression results, significantly positive too. However, the regression results are different from regression results in different industries. The regression results of these control variables are consistent in some industries, though affected by industry nature. 
Table 3. Results of group regression test in five industries

\begin{tabular}{|c|c|c|c|c|c|c|c|c|c|c|}
\hline \multirow{2}{*}{$\begin{array}{c}\begin{array}{c}\text { Explanatory } \\
\text { variable }\end{array} \\
\text { R\&D }\end{array}$} & \multicolumn{2}{|c|}{$\begin{array}{c}\text { Railways, ships, } \\
\text { aerospace } \\
\text { manufacturing and } \\
\text { other manufacturing } \\
\text { industries. }\end{array}$} & \multicolumn{2}{|c|}{$\begin{array}{l}\text { Chemical raw } \\
\text { materials and } \\
\text { chemical products } \\
\text { manufacturing } \\
\text { industry }\end{array}$} & \multicolumn{2}{|c|}{$\begin{array}{c}\text { Computer } \\
\text { communications and } \\
\text { other transport } \\
\text { equipment } \\
\text { manufacturing } \\
\text { industry } \\
\end{array}$} & \multicolumn{2}{|c|}{$\begin{array}{l}\text { Pharmaceutical } \\
\text { manufacturing } \\
\text { industry }\end{array}$} & \multicolumn{2}{|c|}{$\begin{array}{l}\text { Instrument } \\
\text { manufacturing } \\
\text { industry }\end{array}$} \\
\hline & $\begin{array}{c}434 \\
(1.903)\end{array}$ & .061 & $\begin{array}{c}.671 * \\
(3.315)\end{array}$ & .001 & $\begin{array}{c}.218 * \\
(3.352)\end{array}$ & .001 & $\begin{array}{c}.911 * \\
(10.570)\end{array}$ & .000 & $\begin{array}{c}.265^{*} \\
(2.560)\end{array}$ & .011 \\
\hline Serv & $\begin{array}{l}1.370^{*} \\
(8.012)\end{array}$ & .000 & $\begin{array}{l}1.415^{*} \\
(7.590)\end{array}$ & .000 & $\begin{array}{l}1.035 * \\
(9.237)\end{array}$ & .000 & $\begin{array}{c}.403 * \\
(2.523)\end{array}$ & .012 & $\begin{array}{c}.730 * \\
(5.182)\end{array}$ & .000 \\
\hline LnSize & $\begin{array}{c}-.080^{*} \\
(-4.268)\end{array}$ & .000 & $\begin{array}{l}.015 \\
(.850)\end{array}$ & .396 & $\begin{array}{l}.005 \\
(.529)\end{array}$ & .597 & $\begin{array}{c}-.018^{*} \\
(-3.157)\end{array}$ & .002 & $\begin{array}{c}-.119 \\
(3.417)\end{array}$ & .256 \\
\hline Debt & $\begin{array}{l}.014 \\
(.451)\end{array}$ & .653 & $\begin{array}{c}.092 \\
(1.790)\end{array}$ & .075 & $\begin{array}{c}.027 \\
(1.208)\end{array}$ & .227 & $\begin{array}{c}-.065^{*} \\
(-2.470)\end{array}$ & .014 & $\begin{array}{c}.063^{*} \\
(2.142)\end{array}$ & .034 \\
\hline Serv*LnSize & $\begin{array}{l}-.023^{*} \\
(-2.744)\end{array}$ & .008 & $\begin{array}{c}-.028 \\
(-1.831)\end{array}$ & .068 & $\begin{array}{c}-.041 * \\
(-10.754)\end{array}$ & .000 & $\begin{array}{l}-.009 * \\
(-.009)\end{array}$ & .000 & $\begin{array}{l}-.013 * \\
(3.470)\end{array}$ & .001 \\
\hline Serv*Debt & $\begin{array}{c}-.037 * \\
(-4.352)\end{array}$ & .000 & $\begin{array}{c}-.022 \\
(-.962)\end{array}$ & .337 & $\begin{array}{l}.006^{*} \\
(2.605)\end{array}$ & .009 & $\begin{array}{c}.022^{*} \\
(4.710)\end{array}$ & .000 & $\begin{array}{l}.001 \\
(.285)\end{array}$ & .776 \\
\hline $\begin{array}{l}\text { Constant } \\
\text { term }\end{array}$ & $\begin{array}{l}15.265^{*} \\
(7.923)\end{array}$ & .000 & $\begin{array}{l}5.681 * \\
(3.438)\end{array}$ & .001 & $\begin{array}{l}8.913^{*} \\
(8.550)\end{array}$ & .000 & $\begin{array}{l}8.649^{*} \\
(9.029)\end{array}$ & .000 & $\begin{array}{l}9.127^{*} \\
(7.096)\end{array}$ & .000 \\
\hline $\begin{array}{l}\text { Adjusted R }{ }^{2} \\
\text { F statistics }\end{array}$ & 6.006 & .313 & 20.662 & .311 & 14.643 & .422 & 4.802 & .590 & 8.568 & .485 \\
\hline
\end{tabular}

Note: all labeled $*$ are significant at 0.05 level, $\mathrm{t}$ value in brackets, and significant level on the right side.

\section{Conclusion}

Based on the theoretical and empirical analysis, conclusions are as follows:

(1) Marginal return rate of incremental technological input will rapidly decline in high-tech manufacturing enterprises, but high investment risk during bottleneck period due to high technological input. Meanwhile, service factors input has a strong marginal substitution effect on technological elements. Therefore, during technical bottleneck period, choosing service strategy will help to avoid those risks.

(2) Different service performance exists, but empirical analysis shows that there are only "enterprise technological innovation capability" and "service degree" that can affect the service performance among possible factors like industry and enterprise scale. And there is a significant positive correlation between these two variables and service performance.

\section{References}

[1]. Tong Jiadong [J].China's Industrial Economy, 2017, (06): 5-59.

[2]. TangZhifang, Gu Naihua,et al.Manufacturing Services, Global Value Chain Division and Labor Income Ratio: Empirical Research Based on WIOD Data [J].Industrial Economics Research, 2018, (01): 15-27.

[3]. Wang Yangdong,YangYuecheng,ZhaoZhiqiang,et al.Analysis of the connotation, characteristics and causes of high-tech services [J].Science and Science and Technology Management, 2007, (11): $10-13$.

[4]. Li Wenxiu, Chen Xiaoxia, Xia Jiechang,et al.Theoretical and Empirical Analysis on the Source of Performance Difference of Service Enterprises [J].Social Sciences, 2012, (02): 59-64.

[5]. Vandermerwe, S., Rada, J. Servitization of business: adding value by adding services [J]. European Management Journal, 1988, 6, (04):314-324. 
[6]. Markusen J R. Trade in Producer Services and in other Specialized Intermediate Inputs[J]. The American Economic Review,1989,79(1):85-95.

[7]. Wasserman, S., Faust, K. Social Network Analysis: Methods and Applications [M]. Cambridge: Cambridge University Press, 1994.

[8]. Anderson, J., Narus, J. Capturing the value of supplementary services [J]. Harvard Business Review, 1995, (02):75-83.

[9]. Miller, D., Hartwick, J. The problem of solutions: balancing clients and capabilities [J]. Business Horizons, 2002, (04):3-12.

[10]. Kelly D, Storey C. New service development: initiation strategy[J]. International Journal of Service Industry Management,2000,11(01):45-62.

[11]. Cooper R G, Kleinschmidt E J. New product performance: what distinguishes the star products[J]. Australian Journal of Management,2000,25(01):17-45.

[12]. De Brentani U. Innovative versus incremental new business services: different keys for achieving success [J]. Journal of Product Innovation Management,2001,18, (3):169-187. 